\title{
Saúde e Doença na América Latina e no Caribe: Perspectivas Histórico-Sociológicas
}

\author{
LINA FARIA • \\ CARLOS HENRIQUE ASSUNÇÃO PAIVA •
}

\section{HOCHMAN, Gilberto; ARMUS, Diego (Orgs.). \\ Cuidar, controlar, curar: ensaios históricos sobre saúde e doença na América Latina e Caribe. Rio de Janeiro: Editora Fiocruz, 2004.}

A historiografia sobre saúde e sociedade, em língua portuguesa, há tempos não recebe uma contribuição de peso como esta obra, organizada pelo sociólogo brasileiro Gilberto Hochman e pelo historiador argentino Diego Armus. São 14 ensaios, densos, bem escritos, articulados por um olhar que se poderia intitular histórico-sociológico. A coletânea reúne ensaios sobre a saúde pública, a medicina e as doenças na América Latina e no Caribe, entre finais do século XIX e primeiras décadas do século XX. As análises enfocam não só a experiência brasileira com as questões da saúde coletiva, mas também outras realidades, como a argentina, a boliviana, a colombiana, a costarriquenha, a haitiana, a mexicana, a peruana e a porto-riquenha. Traçando aspectos importantes das experiências de cada um desses países, os autores - latino-americanos e latinosamericanistas - discutem o papel da saúde pública, das enfermidades e da medicina na construção institucional da ciência biomédica, na formação das nacionalidades, no delineamento de identidades étnicas, raciais e de gênero, na institucionalização de espaços de cuidado e de cura, bem como de aparatos disciplinares e, finalmente, na montagem de sistemas administrativos governamentais com capacidade para coordenar, executar e fiscalizar as ações de saúde em todo o território nacional.

Vários capítulos da coletânea questionam uma posição corrente na literatura, segundo a qual a comunidade científica dos países periféricos "simplesmente copiou" o mais proximamente possível os princípios e modelos da medicina científica e da higiene moderna dos países centrais, em especial dos Estados Unidos. A coletânea revela, ao contrário, a formação de uma "excelência científica na periferia", ${ }^{1}$ com razoáveis e, em alguns casos, elevados 
graus de autonomia nacional de decisões. Apesar da condição subordinada e periférica da América Latina e do Caribe nos processos de industrialização e urbanização, houve respostas locais e nacionais para os problemas de saúde. Mais do que isto, desenvolveram-se capacidades para solucionar os problemas cotidianos da prática científica, conformando um modelo de ciência e de ação profissional. Para grande parte da comunidade científica latino-americana, o modelo de medicina e saúde pública norte-americano serviu como inspiração, não como imposição. As formações históricas distintas e, particularmente, a marca "nacional" das diferentes tradições médicas, determinaram adaptações que diferenciaram as trajetórias da saúde nos países da América Latina e do Caribe.

A introdução, pelos organizadores, oferece as principais pistas para os leitores: são ensaios com diferentes ênfases, metodologias, objetos de trabalho e estilos narrativos que se integram num projeto comum, de entender como indivíduos, grupos sociais, governos e instituições não-governamentais, nacionais e estrangeiros, se posicionaram em relação à saúde e à doença. Nesse projeto bem-sucedido de autores e organizadores, discute-se a interação entre tradições médicas nacionais e estrangeiras, a montagem dos serviços de saúde, a constituição de movimentos reformistas e ideologias nacionalistas, os diferentes níveis de centralização ou descentralização do poder político, a dinâmica das relações raciais, os processos de burocratização, profissionalização e "resistência à mudança", os padrões de políticas públicas, o papel do pensamento científico e a dimensão estratégica que a saúde assume para os atores políticos nessas décadas decisivas. Como afirmam os organizadores, são experiências, contextos, atores e instituições "tão distantes e diversos e ao mesmo tempo tão próximos e similares" (p. 17).

Passemos à discussão circunstanciada, iniciando com as contribuições que permitem um contraponto mais forte com os temas brasileiros. A literatura tem destacado o papel da Fundação Rockefeller, no Brasil e em vários outros países da América Latina, como importante aliada das propostas de reorganização do campo sanitário e da educação em saúde (CUETO, 1989; CASTRO SANTOS, FARIA, 2003). Os capítulos redigidos por Luiz Antonio de Castro Santos e Steven Palmer abordam tal tema, ao discutirem o padrão de intervenção daquela agência estrangeira no desenvolvimento científico e na formação das "profissões de saúde" em dois países latino-americanos. A discussão dos autores sugere, para o caso brasileiro e costarriquenho, um forte 
componente de parceria com médicos e sanitaristas locais na definição dos objetivos e ações de saneamento e educação médica. Tanto no Brasil, quanto na Costa Rica, a Rockefeller procurou adaptar suas pesquisas e atividades a temas e problemas de cada país. As singularidades dos países atendidos, no tocante às tradições médicas, à diversidade cultural e política, aos movimentos populares e reformistas, por parte das elites locais, afetaram significativamente as relações e interesses da fundação norte-americana na institucionalização da ciência naqueles países. Em muitos países latino-americanos, a atuação da Fundação Rockefeller, sem que a isto se propusesse, acabou por favorecer os projetos de construção nacional, já que os governos federais tiveram de ampliar seus investimentos em programas de higiene, educação e saneamento. O texto de Castro Santos, menos afeito à história das doenças do que à significação sociológica da relação entre reforma sanitária, construção do Estado e as ideologias nacionalistas no início do período republicano brasileiro, parte de uma análise histórico-comparativa entre algumas regiões e suas áreas urbanas e rurais. $\mathrm{O}$ autor focaliza particularmente os anos que se seguiram à criação dos serviços de profilaxia rural em todo o país, em 1918, e à instituição do Departamento Nacional de Saúde Pública, já com foros "ministeriais", inaugurado e chefiado por Carlos Chagas em 1920. Nesta fase, propõe o autor, assiste-se a um processo de "interiorização" e expansão dos serviços de saúde, que teve por lastro uma efetiva participação do Estado na "formulação de ideologias e políticas de salvação nacional por meio da educação e da saúde pública (p. 251). Está em pauta a união fecunda entre o otimismo educacional e sanitário, lembrando as teses do educador Jorge Nagle (NAGLE, 1974). Em segundo lugar, lembra o autor, contou o Estado brasileiro com a aliança estratégica da Fundação Rockefeller. Nesses tempos pré-Vargas diferentemente do que sustenta boa parte da literatura - já se assistia ao enraizamento da "questão" sanitária e de sua transformação em ideologias e políticas de reforma. No tocante ao exemplo da Costa Rica, Palmer enfatiza o debate científico sobre uma endemia em particular, o cansancio, nome que a ancilostomíase recebia popularmente naquele país. Palmer fala de uma "precedência periférica" (p. 221-225), ou seja, da existência de um projeto de saúde pública, de feitura local, e de como grupos intelectuais e instituições costarriquenhos foram capazes de transformar os esforços da Fundação Rockefeller num veículo para a consolidação daquele projeto. Para o autor, um dos fatores que determinaram o êxito da campanha na Costa Rica foi a maturidade de sua rede pública de educação, "um casamento de conveniência" 
(p. 221) entre a saúde e o sistema educativo. Novamente, como no Brasil, ressurge a eficácia simbólica da parceria "saúde e educação". Por outro lado, afirma Palmer, a periferia realmente se adiantou à metrópole na pesquisa e no tratamento da ancilostomíase. O país contava com um ativo núcleo de médicos cientistas já no final do século XIX, que haviam identificado a ancilostomíase como uma doença endêmica em várias regiões do país.

O texto de Jaime Benchimol, "Febre amarela e a instituição da microbiologia no Brasil", aborda mais de perto o caso brasileiro, nos tempos que antecedem e assistem à ação dos pesquisadores e sanitaristas da Rockefeller. É uma contribuição à história conturbada das doenças no país, particularmente da febre amarela. O debate intenso sobre modelos causais, discutido profundamente por Benchimol, serviu de palco para um confronto entre grupos médicos que, para além das controvérsias científicas da época, se valeriam da capacidade de se articularem politicamente - e de se legitimarem em fóruns internacionais - para construírem sua hegemonia nacional. O contexto desse confronto, no interior da elite médica nacional, foi delimitado pelos trabalhos desenvolvidos pela chamada Escola Tropicalista Baiana, em meados do século XIX, e a criação do Instituto Soroterápico de Manguinhos, já na virada do século. $\mathrm{O}$ ator principal dessa trama, o médico brasileiro Domingos Freire, nas últimas décadas do século XIX desenvolveu uma vacina contra a febre amarela. Tratado como herói no Brasil, após a repercussão de seu trabalho em Paris, veria sua carreira entrar em xeque, quando um presidente da American Public Health Association anunciou publicamente que os latino-americanos não haviam ainda produzido uma vacina eficaz. Além de Freire, Oswaldo Cruz, Adolfo Lutz e Vital Brazil foram atores privilegiados na trama e nos debates em torno da etiologia da febre amarela. Na verdade, o ambiente e os ingredientes para a luta antiamarílica já estavam dados naquela época, não apenas nos fóruns estritamente científicos, mas também na imprensa leiga e no debate público. Seguindo as sugestões de Benchimol, basta lembrarmos que, pari passu ao trabalho de Finlay em Cuba e à apresentação de seus resultados no $3^{\circ}$. Congresso Pan-Americano, ocorrido em Havana, em 1901, inúmeras cidades das Américas praticamente já se lançavam ao combate ao mosquito, como ocorreu no interior de São Paulo, logo no início do século passado. As certezas da transmissão exclusiva pelo Aedes aegpti e da teoria dos focos-chave (defendida pela Rockefeller no Nordeste do Brasil) seriam balançadas mais tarde, como revela Benchimol, pelas teses da endemicidade da febre amarela fora dos focos urbanos e da colocação "sob suspeita" da tese da exclusividade do mosquito. 
Em “Eugenia no Brasil, 1917-1940”, Nancy Leys Stepan discute os movimentos eugênicos na América Latina e, em particular, no Brasil, que influenciaram o pensamento científico e social e programas de higiene, em diversos compassos e com resultados diferenciados. Segundo a autora, a literatura tende a oscilar entre a negação cabal das idéias eugênicas no Brasil ou uma confusão com as concepções que desaguaram no racismo nazista. Stepan lembra que o Brasil foi o primeiro país da América Latina a ter um movimento organizado, com a fundação, em 1918, da Sociedade Eugênica de São Paulo. Para Stepan, o caso brasileiro revela traços que o distinguem, científica e ideologicamente, da eugenia nazista e também dos casos anglo-saxônicos, de modo geral. Mais ainda, a origem deste movimento deveria ser entendida a partir do próprio contexto brasileiro. Stepan discute quatro pontos principais, que, segundo ela, influenciaram os rumos do movimento eugenista no Brasil. Um primeiro refere-se à entrada do Brasil na Primeira Guerra, que pôs em primeiro plano noções como "competências" e "capacidades raciais", assim como gerou a crença na necessidade de regeneração nacional (p. 336). Um segundo elemento diz respeito à questão social, resultante da pobreza e da imigração e, em especial, da falta de saúde da população trabalhadora, em grande parte negra e mulata. Um terceiro fator foi o estágio em que a ciência brasileira se encontrava. O movimento eugênico brasileiro derivou não das concepções mendelianas de genética, mas de idéias neolamarckianas, ou seja, de uma abordagem mais sociológica do que biológica sobre as questões raciais. Os lamarckianos, recorda Stepan, acreditavam que, de alguma forma, "a influência do meio poderia alterar permanentemente o plasma germinativo" (p. 347). A eugenia brasileira da década de 1920 não foi, portanto, um movimento de higienização ao estilo nazista, "disposto a esterilizar ou eliminar alguma raça" (p. 356). A identificação da eugenia com saneamento foi uma das conseqüências da importância dada à saúde nesse período. Finalmente, um fator adicional, discutido neste capítulo, refere-se à situação racial do país e ao interesse na modernização. Raça e relações raciais eram temas centrais dos debates sobre a capacidade brasileira e o destino nacional. À medida que a tese do "branqueamento" (p. 369) ganhava terreno, nas décadas de 1920 e 1930, muitos brasileiros começaram a desviar sua atenção do pessimismo racial para a educação, a reforma social e o saneamento, como soluções para o problema nacional. Um certo "otimismo realista" em relação à viabilidade do país passou a fazer parte dos discursos dos médicos brasileiros. A linguagem da eugenia passou a simbolizar, em última análise, um ideal sanitário. 
Beatriz Teixeira Weber assina "Fragmentos de um mundo oculto: práticas de cura no sul do Brasil", uma história que se situa numa espécie de segundo plano, paralela ao processo de institucionalização das ideologias de progresso racial e dos saberes científicos no Brasil. Trata-se de práticas de cura marginalizadas nos discursos oficiais, vivas nos terreiros de batuques e nas práticas de outros rituais afro-brasileiros, como nos das benzedeiras, curandeiros e parteiras. Esses relatos entrecruzam-se, no presente volume, com descrições sobre práticas tradicionais em países como Haiti e Porto Rico. No Brasil, estas práticas populares floresceram sob um contexto regional favorável, como ocorreu, particularmente, no Rio Grande do Sul, durante o século XIX - e mesmo após as novidades advindas da bacteriologia e da microbiologia -, quando os saberes populares ainda constituíam alternativas terapêuticas nada secundárias. Segundo a autora, as práticas destes serviços de cura populares não se restringiam ao combate à doença, concebida biologicamente, mas configuravam um universo de troca de favores e de constituição de laços de solidariedade que marcaram tanto a diversidade cultural da população gaúcha, como os mecanismos de ajuda mútua entre imigrantes ou entre os setores sociais abastados. Beatriz Weber focaliza, em seu texto, o papel social integrador das práticas religiosas e das práticas de cura no extremo sul do Brasil. O catolicismo, como um arranjo cultural mais amplo, favorecia o congraçamento de indivíduos de diferentes origens, fossem italianos, poloneses ou alemães. Dessa forma, a configuração de um catolicismo e de uma medicina populares representou a construção de um arranjo sociocultural híbrido, com a marca da tolerância.

Os temas da raça, do sexo e da intolerância afloram no capítulo de Sérgio Carrara, que acompanha a evolução sócio-histórica do Brasil de entreguerras, tomando a sífilis como a grande metáfora da (falta de) identidade nacional. Segundo o autor, a sífilis foi sempre vista como uma espécie de "símbolo natural" para explicar comportamentos desviantes, imorais e pecaminosos, constituindo um fator explicativo para a suposta "inferioridade" biológica e moral do povo brasileiro. A relação entre miscigenação, sífilis e degeneração estava presente no diálogo de cientistas, médicos, intelectuais e, de modo geral, nas elites brasileiras. A discurso racial da identidade do país, referido por Carrara, remete às questões discutidas por Castro Santos e Stepan, além de constituírem um leitmotiv no texto de Nísia Trindade Lima e Hochman, mencionado adiante. A sífilis era a mais difundida das doenças, "o signo visível da lubricidade e permissividade que caracterizaria os habitantes do país" (p. 432). Por ser uma 
doença estigmatizante, havia a preocupação entre as nações de não serem apontadas como seu reservatório. Lançando mão de conceitos tanto antropológicos como sociológicos, Carrara analisa o processo que fez da sífilis - tradicionalmente a doença do "outro" - uma doença "brasileira". Se, até o início dos anos de 1920, eram geralmente fatores climáticos e raciais (inclusive a miscigenação) que explicavam a inferioridade racial e moral dos brasileiros, o debate entre as elites intelectuais do país tende a reagir contra esse cenário pessimista e negativo do Brasil, e instaura-se, paralelamente, o "otimismo realista" de que fala Nancy Stepan. Explicações climáticas e racialistas, que enfatizavam a degeneração racial nos trópicos, mesmo entre os brancos, passaram a ser sistematicamente criticadas por correntes do pensamento social brasileiro. Para muitos, o dilema brasileiro era social, passível de solução por meio de uma intervenção educativa e sanitária. Quanto à visão que se tinha da sífilis, a doença deslocou o problema racial da miscigenação para o desvio sexual. A sífilis, e não mais a miscigenação, é que teria sido a "influência social" mais perversa sobre a composição da população brasileira (p. 442).

O capítulo "Pouca Saúde e muita saúva: sanitarismo, interpretações do país e ciências sociais", de Nísia Trindade Lima e Gilberto Hochman, passa em revista a história da saúde pública e da ciência social brasileiras, dos anos de 1920 até aproximadamente a década de 1950, e discute a produção acadêmica mais recente sobre os primórdios da reforma sanitária brasileira, durante a Primeira República. Ao seguirem um caminho proposto por Castro Santos em trabalhos anteriores, ${ }^{2}$ sobre o papel primordial que teve a saúde como ferramenta redentora da nacionalidade, Lima e Hochman revelam como temas sanitários se transformam em temas compartilhados entre as mais diferentes tradições profissionais e intelectuais, ganhando força simbólica entre médicos consagrados, advogados, educadores, políticos de diferentes filiações e escritores. Entre estes últimos, Monteiro Lobato foi um crítico profundamente representativo, pois exemplificou os dois momentos descritos por Sérgio Carrara, com suas duas faces do Jeca Tatu (a primeira, um indolente degenerado; a segunda, um doente opilado, a quem Lobato se desculpa pela injusta imprecação da indolência). Mário de Andrade, também referido pelos autores, sintetiza ironicamente o destino de Macunaíma, o herói que se aborrece de penar na terra sem saúde e com saúvas... (p. 508-515). Sob essa ótica, ao mostrarem que a inserção do pensamento social nas questões da saúde tem origens muito anteriores aos debates políticos sobre a reforma sanitária nos tempos de Vargas até o período da ditadura militar, ${ }^{3}$ os autores convidam a repensar a saúde pública na América 
Latina sob uma perspectiva histórica de longo alcance. Nessa mesma medida, recuperam os laços, construídos desde a Primeira República, entre educação, saúde e pensamento social.

A perspectiva histórica mais ampla é discutida em "Profissões da saúde e lutas de poder no México, 1821-1917”, por Ana Maria Carrillo. A autora focaliza o processo de profissionalização e de institucionalização da autoridade da medicina no México, ao longo do século XIX e até o início do século passado. No percurso, a autora nos revela as estratégias e as lutas da incipiente corporação médica colonial, bem como do México independente, frente a determinados grupos sociais que, aos olhos dos médicos, representavam concorrência. Eram indivíduos dotados de saber popular ou "não-científico", além de segmentos que, em nome da ciência, disputavam processo similar ao dos médicos, de legitimação social e científica, como era o caso das parteiras diplomadas. Tal como no Brasil imperial, faz parte dessa história a edificação de academias científicas e a criação de periódicos que divulgavam as teorias e premissas científicas durante o período. A exemplo da imprensa científica brasileira, muitos periódicos mexicanos foram veículos poderosos de adesão e congraçamento das elites médicas locais, embora também representassem o palco de conflitos e querelas científicas. Outro aspecto que chama atenção - e ainda comparativamente ao Brasil - é a quantidade de faculdades de medicina instaladas prematuramente no México. Até o século XIX criaram-se nove faculdades, sendo a primeira, em Guadalajara, fundada em 1792. Nesse ponto o trabalho de Carrillo se integra ao debate sobre as instituições de ensino nas Américas portuguesa e espanhola.

A este respeito há, de um lado, analistas que consideram que a colonização espanhola na América permitiu conscientemente e muito cedo a criação de universidades, tendo em vista a coexistência de grupos indígenas cultural, política e economicamente mais sofisticados - se comparados àqueles encontrados na colônia portuguesa - em um território geograficamente mais diversificado, sob vários aspectos. Este arranjo de características exigiria de Castela a criação de um aparato técnico burocrático mais organizado (PRADO, 1994). De outro lado, há estudiosos que consideram que as instituições de ensino criadas por Portugal no Brasil teriam cumprido papel similar àquelas instaladas na colônia espanhola. Esta hipótese repousa sobre o argumento de que os seminários jesuítas eram equivalentes aos cursos de nível superior hispanoamericanos (CUNHA, 1986). Fosse um ou outro o papel imputado às instituições 
de ensino, Carrillo considera que a existência de universidades, de cursos formais e de associações médicas permitiu não apenas maior coesão da profissão médica, mas igualmente uma maior legitimidade dos profissionais frente ao Estado. Um último ponto, já rapidamente sinalizado, trata das diferentes atitudes dos médicos frente a outros grupos que se profissionalizavam, como os cirurgiões, os dentistas, os homeopatas, num contexto em que a grande massa da população mexicana recorria, não aos saberes oficiais, mas à medicina popular e indígena. Ainda que a história traçada por Carrillo destaque o avanço do saber médico, na passagem de um século ao outro, rumo a sua institucionalização frente ao Estado e à sociedade - com a criação de todo um aparelho técnico-burocrático e jurídico que ampararia as políticas médicas -, o fato é que os saberes fundados nas experiências populares e nas tradições mais remotas jamais se veriam de todo excluídos das representações e das práticas sociais do curar. Essa é uma lição que também se depreende do texto de Beatriz Teixeira Weber sobre as práticas de cura no sul do Brasil, na época da Primeira República. Embora a absorção e a utilização de diferentes tradições terapêuticas, por parte dos sistemas de saúde oficiais, sejam um fenômeno relativamente recente na América Latina, ${ }^{4}$ há contextos em que esta verdadeira integração se manifestou cedo, como demonstra, por exemplo, o artigo de Marcos Cueto nesta coletânea.

“Tifo, varíola e indigenismo: Manuel Núñez Butrón e a medicina rural em Puno, Peru" é a contribuição do historiador peruano Marcos Cueto. No Departamento de Puno, região pobre no sul do Peru, o personagem de relevo é o médico católico Núñez Buttrón, filho ilegítimo de um padre e de uma mestiça, que estudou medicina em Barcelona, na Espanha, onde era discriminado como "índio". O estigma levou-o, não a uma crise de identidade, mas, ao contrário, a um reencontro de suas raízes indígenas (p. 304). De volta ao Peru, em 1925, teve papel importante na organização da comunidade indígena para o combate a doenças, sobretudo à varíola e ao tifo epidêmico. A primeira "brigada sanitária" (p. 302), organizada pelo médico, em 1933, constitui exemplo de cooperação e organização comunitária, a partir de um arranjo político favorável, marcado pela presença de religiosos adventistas preocupados com a higiene, pela disponibilidade de alguns recursos, provenientes dos latifúndios da região, e pela disseminação da ideologia do indigenismo entre os intelectuais. Esse conjunto de fatores tornou disponível, em linguagem de nossos dias, recursos financeiros e humanos favoráveis ao ambiente de reforma. $\mathrm{O}$ voluntariado foi ingrediente fundamental no arranjo que permitiu a disseminação das idéias sobre higiene, a utilização da educação sanitária como instrumento de diálogo e persuasão, por 
parte das autoridades sanitárias e membros da comunidade, com a vantagem do respeito a tradicionais métodos de terapia utilizados pelos índios da região. Envolvido com a política indigenista e a organização comunitária local, seu "sanitarismo indigenista", ou seu "indigenismo médico" (p. 316) encontrou duras resistências, particularmente dos poderosos, que passaram a temer "que os índios se tornassem mais hábeis na defesa de seus direitos" (p. 317), e dos comerciantes locais, que se irritavam com as campanhas contra o uso do álcool, um dos pontos de honra das lutas do médico e de seus seguidores. Havia um elemento de autoritarismo ou caciquismo na conduta militante de Núñez Buttrón. Isso em parte permitiu que o próprio movimento se enfraquecesse sem seu líder, já no final da década de 1940, quando, alvo de pressões políticas, foi transferido de suas funções como médico do Estado. Suas lições e sua história, no entanto, se fazem especialmente pertinentes, tendo em vista a força do atual debate em torno da participação popular em saúde, da integração dos saberes e terapias tradicionais e do papel da educação em saúde na erradicação das doenças.

A luta antialcoólica não era parte da agenda sanitarista apenas no caso peruano, estudado por Cueto. Também na Colômbia, como mostra Carlos Ernesto Noguera, em seu capítulo sobre a "higiene social" no altiplano, o alcoolismo era combatido por médicos e higienistas já no final do século XIX. O ataque se fazia particularmente contra o uso da bebida chicha - feita da fermentação do milho e a mais consumida pela população na cordilheira oriental dos Andes colombianos. Segundo Noguera, o alcoolismo era visto pelos médicos como uma "enfermidade social", assim como a sífilis, a loucura, a lepra e a tuberculose, cujas consequiências mais evidentes eram e degeneração física e moral do indivíduo. Neste sentido, médicos e higienistas colombianos passaram a utilizar argumentos científicos da época - dosados por fortes conotações raciais - diante dos comportamentos e hábitos da população pobre colombiana. Segundo o autor, apresentavam a bebida como um entrave à modernização do país. Para a classe médica e em particular para os higienistas, "o alcoolismo foi visto como um verdadeiro veneno racial e, por conseguinte, inimigo do progresso" (p. 116117). Neste sentido, a campanha contra a chicha, bebida ancestral indígena, foi, segundo Noguera, uma reação moderna a costumes e hábitos tradicionais. Mas, acrescenta o autor, se a luta antialcoólica pareceu acabar com um vício popular, na verdade apenas instaurou o uso "moderno" das cervejas entre as camadas populares.

No contexto do movimento pela independência de Porto Rico, ao findar do século XIX, situa-se o artigo de Benigno Trigo, "Anemia, bruxas e vampiros: 
figuras para governar a colônia". Tendo como cenário os processos da precária formação do Estado porto-riquenho, Trigo promove, de um lado, uma discussão em torno da questão da identidade nacional, fragilizada pelas imagens do negro, tido como parasita e disseminador de doenças. Reformistas liberais nativos, segundo Trigo, procuravam legitimar-se diante dos europeus e retirar dos próprios ombros a premissa colonialista que atribuía aos americanos males determinados pela combinação de fatores genéticos e ambientais. A vadiagem, a preguiça e a promiscuidade - os males então atribuídos a todo porto-riquenho - ganharam então cor e foram transferidos aos escravos recém-libertos, em 1873. A inferioridade como metáfora racial do corpo negro foi trabalhada em outro sentido, agora como decorrência da anemia, que afetava o sangue "predominantemente branco" da camponesa porto-riquenha. De acordo com o médico e literato ilhéu Francisco Del Valle Atiles, a "camponesa anêmica" era vítima do mosquito, que se assemelhava a um vampiro. "O mosquito [...] como os vampiros, move-se invisível de lugar a lugar", cita Benigno Trigo (p. 140). Assim, Atiles sugere a contaminação da "raça", empregando o discurso científico sobre a anemia, que julgava "causada" por mosquitos. Dada a suposta resistência física dos africanos, Del Valle Atiles alertava em 1887 que, "se a anemia não fosse controlada, a 'raça africana' floresceria" em seu país (p. 141). Esse triste prognóstico se fundava nos preceitos da eugenia, "a base mais firme de nosso progresso", asseverava o cientista anos mais tarde (p. 156). O "vampiro" idealizado pelo médico, assim como os "bruxos", que praticavam a medicina indígena (inclusive as parteiras, p. 144-145), constituíam-se nas metáforas que traduziram o alto grau de ideologização da ciência porto-riquenha. Inspirado em teses eugenistas, Del Valle Atiles sugeriu práticas que tinham como meta o controle de uma população rural considerada racialmente inferior. Trigo contrapõe a atuação dos "letrados", que se posicionavam contra a administração espanhola, mas aceitavam o discurso eugênico, à atuação dos médicos norte-americanos na Ilha, durante a guerra hispano-americana, quando a medicina de laboratório é interpretada por algumas correntes dos "letrados" (e por Trigo) como um discurso do colonizador (p. 153-154). ${ }^{5}$ Trigo tem razão ao afirmar que médicos como Bailey Ashford, da Comissão de Saúde do Exército que ocupou Porto Rico, em 1899, propagaram a medicalização da sociedade como uma ferramenta simbólica de superação do atraso. Parece-nos discutível, no entanto, sua interpretação de todo ato médico contra a ancilostomíase como "intensamente invasivo" (p. 150). Do mesmo modo, seu comentário sobre a "intervenção desfiguradora" (p. 149) de Ashford, quando retira a amostra de 
sangue de uma criança, nos parece, este sim, um procedimento desfigurador, como se relatasse uma história de horrores. ${ }^{6}$

Não é outra a crítica que faz Diego Armus, companheiro de Hochman na organização do volume, aos excessos das apreciações sobre o "intervencionismo" no gesto do cuidar, que o reduzem esquematicamente a um ato de "controle". No capítulo intitulado "'Queremos a Vacina Pueyo!!": incertezas biomédicas, enfermos que protestam e a imprensa" (Argentina, 1920/ 1940), Armus constrói uma análise histórico-sociológica da relação entre tuberculose, medicina e sociedade. Ao fazê-lo, o autor corta fundo no viés foucaultiano, criticando particularmente seus seguidores por construírem "um sujeito fundamentalmente passivo", já que o processo de medicalização the teria negado "qualquer possibilidade de protagonismo" (p. 396 e 423). Armus mostra em seu trabalho que, mesmo em posição de subordinação ao poder médico, o tuberculoso em vários momentos tergiversou, negociou e assumiu posições de confronto. Postou-se não apenas diante do saber profissional, mas também da administração pública, cobrando a adoção de medidas sociais e médicas e atraindo o apoio da imprensa. Em trabalho anterior, Armus revelou a mobilização dos obreiros anarquistas em torno da tuberculose, na Argentina dos anos anteriores a Perón, época de intenso processo de politização das questões de saúde (ARMUS, 1996). Os dois trabalhos se complementam admiravelmente, pois permitem que se entenda a ebulição política que conduziu ao protesto popular. Os protestos exigiram que as autoridades sanitárias colocassem à disposição dos tuberculosos a tão contestada vacina Pueyo, produzida pelo bacteriologista Jesús de Pueyo. Armus mostra a forte resistência do establishment médico, do Departamento Nacional de Higiene e do Congresso Nacional a essa vacina, pela "posição marginal" que ocupava Jesús Pueyo no meio acadêmico. O debate sobre a (in)eficácia da vacina tornou-se uma questão pública na Argentina. Desta feita, assistimos ao uso da simbologia sobre o "vampiro", mas não nos mesmos termos daquilo que se passava em Porto Rico. Em princípios de 1941, as manchetes anunciavam uma iminente "rebelião dos tuberculosos em toda a nação" e que havia chegado a hora dos que "chupam o sangue do povo" (p. 414-415). Os tísicos haviam se mobilizado e lançado um manifesto à nação, "com Pueyo e por Pueyo [e] contra a burocracia capitalista da medicina" (p. 416). Para o movimento anarquista, burocracia e capitalismo, com efeito, eram sinônimos de vampirismo dos poderosos. Mas a análise sensível do autor não sugere que os enfermos tivessem chegado a influir de modo ponderável nos processos decisórios. O protagonismo era real, mas 
limitado (p. 422). Como no Brasil, nessa mesma época, as políticas de saúde ainda emanavam "do alto", e não resultavam diretamente da participação ou de manifestos dos movimentos populares.

Focalizando a Bolívia entre 1935 e 1950, Ann Zulawski examina os preceitos sobre a demência e as práticas terapêuticas entre as autoridades médicas, por meio do estudo de registros clínicos e dos livros do Manicômio Pacheco - a primeira e até então a única instituição no tratamento de doentes mentais da Bolívia, fundado em 1884. Os "anos de convulsão social e política exacerbada pela Guerra do Charco com o Paraguai" (p. 459) ressaltaram, segundo Zulawski, todas as contradições de etnia e classe no país. O clima político em transformação trouxe, segundo a autora, novas iniciativas no campo social e da saúde pública. Em menos de dois anos foram criados dois ministérios voltados para questões de trabalho, saúde e higiene. (O segundo deles, em 1938, foi o "Ministerio de Higiene y Salubridad"). Foi um período de efervescência, também, no campo acadêmico. Médicos interessados em saúde mental começaram a publicar trabalhos sobre psiquiatria e questões sociais. A autora examina a forma como os médicos entendiam os distúrbios emocionais e as capacidades intelectuais de índios, mulheres e grupos miscigenados, considerados sem voz na Bolívia nas primeiras décadas do século XX. Classe, raça, gênero e distúrbio mental estavam profundamente relacionados nos discursos médicos. Os dados estatísticos trazidos pela autora sobre cura e mortalidade dentro do Manicômio mostram as hierarquias de classe e de gênero, presentes nas diferenças de tratamento prestado aos internos. De novo, os leitores constatam, na experiência boliviana, como de resto também no Peru e na Colômbia - para citar dois dos países vizinhos, discutidos no presente volume -, a mesma idiossincrasia racial dos intelectuais e das oligarquias agrárias em relação à população indígena, considerada mentalmente incapaz (p. 457). Do mesmo modo havia, no pós-guerra, discursos alternativos ao estigma da "declinación mental del índio", como os do sociólogo José Antonio Arze, que representava uma corrente de ideais democráticos, avessos à discriminação e ao discurso da inferioridade racial (p. 458).

Vizinho ao Porto Rico estudado por Benigno Trigo, o pequeno Haiti é abordado, em estudo etnográfico histórico ou "processual" (p. 563), pelo antropólogo Paul Farmer. Estamos diante do único capítulo que trata de tempos recentes. A enfermidade, igualmente, é recente: o autor debruça-se sobre a evolução da Aids e as representações em torno da doença, entre 1983 e 1990, no interior do Haiti. A pesquisa retrata a mudança de significados coletivos a 
respeito da epidemia, lançando mão de relatos de pessoas entrevistadas (Farmer domina a idioma crioulo, de base francesa) e da narrativa sobre a dramática trajetória de alguns portadores do HIV. Do desconhecimento praticamente generalizado por volta de 1983, passando pelo registro do primeiro caso de Aids em Do Kay, em 1986 - ano que coincide com a queda da ditadura Duvalier - até os últimos anos da década, o autor constrói o imaginário coletivo da enfermidade como duas entidades, nem sempre claramente delineadas (p. 556): a "Sida" como "doença mandada", causada por feitiçaria; e a doença "infecciosa", associada a um certo "paradigma do sangue" ou ao "paradigma da tuberculose", como explica o autor (p. 542). No primeiro caso, cerimônias Kongo, dirigidas por sacerdotes vodus (p. 536), podem combater uma doença "mandada"; no segundo caso, amuletos talvez nada adiantem e os postos de saúde rurais serão procurados. A imprensa norte-americana, por muito tempo, acusou os haitianos de terem propagado o vírus da Aids no continente, na conhecida tramóia de culpabilizar a vítima. Entre os haitianos, Farmer surpreendeu explicações que pagam na mesma moeda: a epidemia teria sido parte de um plano norte-americano "para escravizar o Haiti. [...] Duvalier costumava vender nosso sangue lá, para transfusões e experiências. Uma dessas experiências foi fazer uma nova doença" (p. 543). O autor coloca a questão de modo contundente: o fato é que a doença "reverbera associações com o contexto político maior, com o imperialismo norteamericano, com a falta de solidariedade entre os pobres e com a corrupção da elite governante do Haiti” (p. 556). Estamos diante de um caso de omissão, por parte dos norte-americanos, ou da exploração da população haitiana como força de trabalho servil nos Estados Unidos? Em qualquer caso, a irresponsabilidade moral contrasta fortemente, segundo as análises feitas no presente volume, com a presença de pesquisadores, sanitaristas e enfermeiras da Rockefeller em outros países da América Latina, muitas décadas antes da Aids.

Cuidar, controlar, curar: ensaios históricos sobre saúde e doença na América Latina e Caribe é uma obra fundamental. Os autores discutiram as relações de poder, o Estado, as políticas, as instituições e os profissionais (legítimos ou "charlatães") de saúde. No período estudado, o empenho de médicos, sanitaristas e higienistas no combate às enfermidades sociais, dentre as quais se destacavam a ancilostomíase, a lepra, a tuberculose, o alcoolismo, a doença mental e a sífilis, mostra a construção - não um simples "transplante" de um modelo de atenção à saúde, que ficou conhecido como "higienistaeducacional". Esse modelo viria a se tornar importante nos países da América Latina, apontando para iniciativas públicas na área social. 
Mais do que isto, o debate em torno de questões como "raça", "miscigenação" e "cultura", discutidas pelos autores, gerou um ambiente propício às reformas preconizadas por higienistas, médicos e sanitaristas. Logo após a passagem do século, a saúde passou a ser vista como uma questão nacional, com desafios que os movimentos de mudança procuraram enfrentar. Os autores revelam, no entanto, alguns dos fortes descompassos da política em toda a América Latina, que acabariam por produzir as brutais iniqüidades nos sistemas de saúde em tempos recentes - como demonstra o capítulo sobre o Haiti, que fecha o volume, como numa premonição.

\section{Referências}

ARMUS, Diego. Salud y anarquia: la tuberculosis en el discurso libertário argentino, 1870-1940. In: CUETO, Marcos (Org.). Salud, cultura y sociedad em América Latina: nuevas perspectivas históricas. Lima: IEP, 1996.

CASTRO-SANTOS, Luiz A. O pensamento sanitarista na Primeira República: uma ideologia de construção da nacionalidade. Dados - Revista de Ciências Sociais, Rio de Janeiro, v. 28, n. 2, p. 193-210, 1985.

CASTRO-SANTOS, Luiz A.; FARIA, Lina. A Reforma Sanitária no Brasil: ecos da Primeira República. São Paulo: Editora Universitária São Francisco, 2003.

CUETO, Marcos. Excelencia cientifica em la periferia: actividades científicas e investigación biomédica en el Peru. Lima: Consejo Nacional de Ciencia y Tecnologia, 1989.

CUNHA, Luiz Antônio. A Universidade temporã. Rio de Janeiro: Francisco Alves, 1986.

ESCOREL, Sarah. Saúde Pública: utopia de Brasil. Rio de Janeiro: RelumeDumará, 2000.

FARIA, Lina. Um americano nos trópicos. História, Ciências, Saúde Manguinhos, v. V, n. 3, p. 705-715, 1999.

NAGLE, Jorge. Educação e sociedade na Primeira República. Rio de Janeiro: DP\&A Editora, 1974.

PRADO, Maria Lígia. Universidades e sociedade na América Colonial. In: 
GEBRAN, Philomena; LEMOS, Maria Teresa T. (Orgs.). América Latina: cultura, estado e sociedade. Rio de Janeiro: Anphlac, 1994.

WEBER, Beatriz Teixeira. Positivismo e ciência médica no Rio Grande do Sul: a Faculdade de Medicina de Porto Alegre. História, Ciências, Saúde Manguinhos, v. 5, n. 3, p. 583-601, 1998.

\section{NOTAS}

- Historiadora, Pesquisadora-Fapesp de Pós-Doutorado, Departamento de Política Científica e Tecnológica, Unicamp. Endereço eletrônico: 1faria@ige.unicamp.br.

- Historiador, Doutor em Saúde Coletiva, Pesquisador Visitante na Casa de Oswaldo Cruz Fiocruz. Endereço eletrônico: chapaiva@gmail.com.

${ }^{1} \mathrm{Na}$ acepção cunhada em Cueto (1989).

${ }^{2}$ Ver, por exemplo, Castro Santos (1985).

${ }^{3}$ Consulte-se uma obra-chave sobre esse período, de Sarah Escorel (2000).

${ }^{4}$ Nem sempre tão recente, talvez. Em outro trabalho, Beatriz Teixeira Weber esclarece que mesmo os sistemas médicos e sanitários “oficiais”, no Rio Grande do Sul, não estavam livres de grandes disputas teóricas, no início do século passado. (Ver Weber, 1998).

${ }^{5}$ Na página 154, alusão a um paper de W. Anderson sobre o laboratório médico como "discurso colonial".

${ }^{6}$ Anos mais tarde, em 1916, Ashford integrou a segunda comissão médica enviada ao Brasil pela Fundação Rockefeller, estabelecendo contatos com os pesquisadores de Manguinhos. Nesse mesmo ano, criou serviços de dispensários rurais na ilha de Porto Rico (ver Faria, 1999). 